\title{
THE CONCEPT OF TAWHID IN ISLAM: IN THE LIGHT OF PERSPECTIVES OF PROMINENT MUSLIM SCHOLARS
}

\author{
Asma Kounsar \\ Shah-i-Hamadan Institute of Islamic Studies, \\ University of Kashmir, Srinagar, Jammu and Kashmir
}

\begin{abstract}
The concept of tawhid excludes man's commitment to anyone other than Allah $(S W T)$. Also a rejection of all sources of value other than will of Allah (SWT), all authority but His, and a refusal to accept any idea, command, or injunction from anyone, as man does from Allah $(S W T)$, on the basis of its having not come from Him. Love or reverence, worship or submission, and a sense of obligation, all are directed towards Allah (SWT) alone and no one else deserves them in the ultimate, full sense of these attitudes. In the human context it means emancipation and restoration of man's essential freedom from all human bondages before the commitment to Allah $(S W T)$. Man is under no obligation to submit to any authority or commit to anyone's will. He owes nothing to any being other than Allah (SWT). He has no superiors except Him. A lot has been written on the topic of tawhid by different scholars but a concise paper which would analyze different perspectives of different scholars on the issue of tawhid has been long awaited. To fill the gap this paper attempts to provide the reader with such information; highlightens the richness in thought and contents with respect to the concept of tawhid and the distinctive views on the same by some prominent Muslim scholars both from the classical and modern era.
\end{abstract}

Keywords: tawhid, Tabari, Ibn Kathīr, Mufti Muhammad Shafi, Maududi, Amin Ahsan Islahi, Ismail Raji al-Faruqi

\section{Introduction}

The Islamic worldview is based on two primary sources; the Qur'ān and the Sunnah, which incorporates the tradition concerning the life example of Prophet Muhammad $(S A W)$. However, the nucleus of both is the principle of tawhid which provides motivation to all that there is in Islamic thought. It is associated with the concept of din, which is translated in modern times as "religion" but has a broader sense of including creed, normative standards, and the whole range of standard behaviour. The Qur'ān affirms that with God, the din is al-Islam (3:19), which can be translated more generally as stating "with God, the true way is submission" or more specifically "with God, true religion is Islam." Islam is the final and complete way of life that God revealed to guide humanity. Previous divine messages (such as the ones taught by Abraham, Moses and Jesus) have been lost or altered throughout time. Therefore,

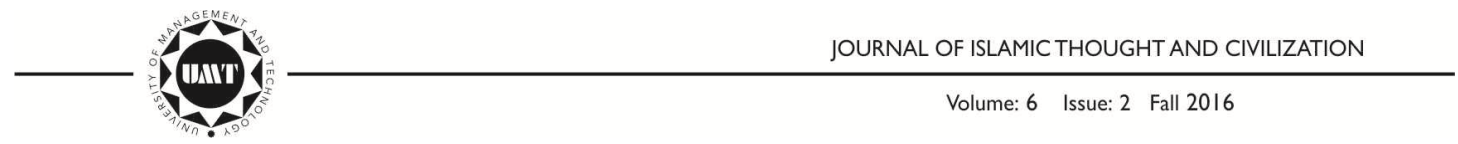




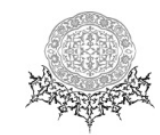

God chose to send His last messenger, Muhammad ( $S A W)$ to deliver His message which maintains the core teachings of all the previous revelations. The word 'Islam' suggests more than a system of theology. It stands for a distinctive civilization and a socio-politico-economic order, based on a form of practical theology. It is not a new way of life, rather it is a final message, which upholds the same essential beliefs that God sent to humanity through all of His messengers $(A S)$. Through this message, God calls on each individual to lead a conscientious life by drawing close to Him and to remain cognizant of their final accountability in front of one and only God. Islam is the religious, social and legal identity that signifies membership in its worldwide, one nation called ummah, with all the rights and responsibilities this membership entails; faith is a personal commitment to a way of life and worship whose sincerity and insincerity God alone can judge. According to the well attested Prophetic tradition, $(S A W)$ Islam is assembled on five pillars. ${ }^{1}$ These five pillars are the fundamental principles or foundations of Islamic faith and Worship. All except the first are both personal and communal enactments of worship. Without them, Islam as an allembracing religious, social, political and economic system cannot stand. ${ }^{2}$

\section{The Concept and Importance of Tawheed}

The concept of tawhid encapsulates the Islamic world-view. It is the basis of Islamic culture and civilization. Knowledge, social action and social organizations in Islam are based on the world-view defined by tawhid. Tawhid defines the relation between the human and the creator as well the relationships among the various creations in the universe. The One God, known by His Arabic name Allah (SWT), is the core of Islam in all of its facets, and attestation to this Oneness, tawhid, is the axis around which all that is Islamic revolves. Allah $(S W T)$ is beyond all relationality and duality, beyond the differences of gender and of all qualities that distinguishes beings from each other in this world. Yet, He is the source of all existence and all cosmic and human qualities as well as the End to whom all things return. At the heart of Islam stands the reality of God, the One, the absolute and the infinite, the infinitely good and merciful, the one who is at once transcendent and immanent. The first of the five pillars is the shahadah: "I bear witness that there is no god except Allah (SWT), and I bear witness that Muhammad $(S A W)$ is the messenger of God." This shahadah is not the creed or a philosophical argument. It is simply a testimony or witness to what the Qur'ān asserts to be a primordial fact; "God bears witness that there is no god but $\mathrm{He}$, as do the angels or those who are possessed of knowledge."3 It means that knowledge of God's Oneness (tawhid) is true knowledge; it is true Islam, the antithesis of jahilliyah. ${ }^{4}$

\footnotetext{
${ }^{1}$ Abu Abdullah Muhammad b. Ismail, Sahih al-Bukhari (Kitab Bhawan, New Delhi, 1984), "Kitab al-Iman," Hadith. No. 7.

${ }^{2}$ Mahmoud M. Ayoub, Islam Faith and History (Oxford: One World, 2006), 55.

${ }^{3}$ Al-Qur'ān āl-Imran 3:18.

${ }^{4}$ Mahmoud M. Ayoub, Islam Faith and History, 55.
}

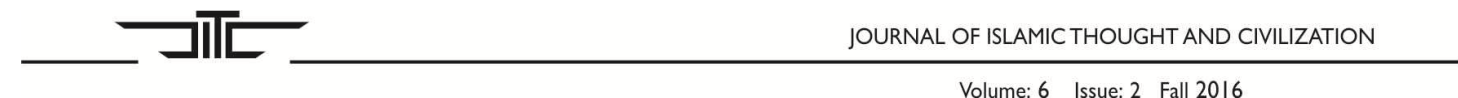


Tawhid is considered as the fundamental principle of Islam, and this principle not only frame the Islamic worldview, but also constitutes the fountainhead of the maqasid (objectives) and the strategy of man's life in this world. This principle also lays the foundation of Islamic social order, which teaches man that his socioeconomic activities must be guided by the principles from a single common source, Allah $(S W T)$. This single common source reveals its principles through the Holy Qur'ān which are elaborated by the Sunnah. The knowledge of tawhid pertains to what it means to be human. It lies in the original human nature (fitrah), since human beings were created knowing that 'There is no god but Allah.' In the Qur'ān it says, "So set (O Muhammad $(S A W)$ your face towards the religion (of pure Islamic Monotheism) Haneef (worship none but Allah's fitrah [i.e. Allah 's Islamic Monotheism] with which He has created mankind. No change let there be in Khalqllaah (i.e. the religion of Allah ), Islamic Monotheism), that is the straight religion." The messenger of Allah ( $S A W$ ) also said that, "Every child is born in a state of fitrah, then his parents make him a Jew or Christian or a Magian.",6

He did not say that they make him Muslim, because Islam is in accordance with the fitrah. Parents, writers, teachers and others instill into children's minds ideas which change and contaminate this fitrah, placing veil over the fitrah so that they are not able to turn towards the truth. ${ }^{7}$ Thus the prophets $(A S)$ were sent to remind them of what they already know. Hence, to associate other with God is to go against the most fundamental instincts of the human nature. It is to betray human nature and even to leave the domain of human existence. This explains why it is such a grave sin. It is the overturning of what makes us human. In this view of things, claiming ignorance of tawhid is tantamount to claiming not to be human. ${ }^{8}$ The concept of tawhid, by emphasizing belief in One Creator and Sustainer of the whole universe, gives human civilization a beginning and an end. It gives it purpose, an objective and a sense of direction. It is an integrating concept without which an ever-lasting and successful civilization cannot be built. Many human civilizations that history has recorded could not sustain themselves beyond a few centuries because of lack of this central integrating vision, tawhid. Thus, they soon run into contradictions and collapsed.

\section{Tawhid in the Light of the Qur'ān}

Belief in the existence of Allah (SWT) and in His Unity is the fundamental doctrine of Islam. It is inconceivable for anyone who claims to be a Muslim to deny the Unity of Allah. For a Muslim belief in the Unity of Allah is axiomatic, for which no argument

${ }^{5}$ Al-Qur'ān,Rūm, 30:30.20

${ }^{6}$ Sahih al-Bukhari, Hadith. No. 1385.

${ }^{7}$ Umar S. al-Ashgar, Belief in Allah (SWT), in the Light of Qur'ān and Sunnah (Riyadh: International Islamic Publishing House), 114.

${ }^{8}$ Sachiko Murata and William Chittick, The Vision of Islam, The Foundation of Muslim Faith and Practice (London: I.B. Tauris, London), 50.

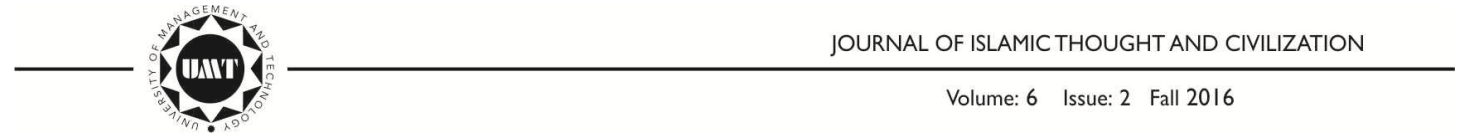




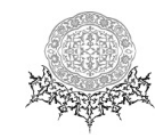

is needed. As, however, the Holy Qur'ān is not only a book of guidance for the righteous, those who fear Allah, but it is also a guide to mankind in general, the Qur'ān contains hundreds of arguments to impress upon the Unity of Allah. The Qur'ān testifies: 'And your God is one God [Allah there is no god but He, Most Gracious, Most Merciful.",

The Unity of God, according to the Holy Qur'ān, implies that God is One in His person $(d h \bar{a} t)$, One in His attributes (sifāt) and One in His works $\left(a f^{\prime} \bar{a} l\right)$. His Oneness in His Person means that there is neither plurality of gods, nor plurality of persons in the Godhead; His oneness in attributes implies that no other being possesses one or more of the Divine attributes in perfection; His Oneness in works implies that none can do the works which God has done, or which God may do. The doctrine of Unity is beautifully summed up in one of the shortest and earliest chapters of the Holy Qur'ān: "Say Allah is unique, Allah the source (of everything). He has not fathered any. One nor was He fathered and there is nothing comparable to Him." 10

The nature of Allah is indicated in a few words, such as we can understand. The qualities of Allah are described in numerous places throughout in the Qur'ān. The believers are specially taught to avoid the pitfalls into which men and nations have fallen at various times in trying to understand Allah. The first thing to note is that His nature is so sublime, so far beyond our limited conceptions, that the best way in which we can realize Him is to feel that He is a Supreme Personality, and not a mere abstract conception of philosophy. He is near us; He cares for us; we owe our existence to Him. Secondly, He is the One and Only God, the Only One to Whom worship is due; all other things or beings that we can think of are His creatures and in no way comparable to Him. Thirdly, He is Eternal, without beginning or end, Absolute, not limited by time or place or circumstance, the Reality before which all other things or places are mere shadows or reflections. Fourthly, we must not think of Him as having a son or a father, for that would be to import human qualities into our conception of Him. Fifthly, He is not like any other person or thing that we know or can imagine: His qualities and nature are unique.

\section{Tawhid in the Teachings of Prophet Muhammad (SAW)}

Allah (SWT) sent his Messenger ( $S A W$ ) to call people to the tawhid and to forbid them from committing shirk. Prophet (SAW) performed this in the best possible manner and suffered a lot for the sake of Allah . In the teachings of Prophet Muhammad (SAW) faith in One God is the most important and fundamental principle. It is the bedrock of Islam and the mainspring of its power. All other beliefs, commands and laws of Islam stand firm on this foundation as mentioned in numerous Hadith of Prophet (SAW). It is narrated by Ibn Abbas (RA) When the Prophet ( $S A W)$ sent Mu'adh to Yemen, he

\footnotetext{
${ }^{9} \mathrm{Al}-\mathrm{Qur} ’ \mathrm{a} n$, al-Baqara 02:163.

${ }^{10} \mathrm{Ibid}, 112: 1-3$.
}

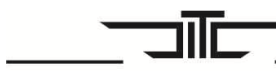

JOURNAL OF ISLAMIC THOUGHT AND CIVILIZATION

Volume: 6 Issue: 2 Fall 2016 
said to him, "You are going to a nation from the people of the Scripture, so let the first thing to which you will invite them is to testify the tawhid of Allah (i.e., "laa ilaaha illallaah,' none has the right to be worship but Allah. If they accept that, tell them that Allah has enjoined on them, five compulsory congregational salah (prayers) to be offered in one day and one night. And if they offer their prayers, tell them that Allah has enjoined on them zakah of their properties; and it is to be taken from the rich among them and given to the poor among them. And if they agree to that, then take from them zakah, but avoid the best property of the people." 11

In another Hadith Umar ibn al-Khattab $(R A)$ reported,

We were seated once near the Apostle of Allah $(S W T)$ and there appeared a person to us, a person fully dressed in white clothes and had jet black hairs. No fatigue of journey did appear on him till he sat down near the Prophet. There he joined his knees to his knees and placed both his palms over his two thighs and said: $\mathrm{O}$ Muhammad $(S A W)$ inform me about Islam. He replied: Islam is that you attested there is no Lord but Allah (SWT) and that Muhammad $(S A W)$ is the messenger of Allah $(S W T)$, that you keep up prayer, pay poor rate, keep fast of Ramadan and make pilgrimage of the House, provided if you have means of making journey to it. He replied: you have spoken the truth; we were astonished to see that he were asked him and corroborated him. Then he departed. The Messenger of Allah $(S A W)$ kept silent for some time and then addressed me: O Umar, do you know about the enquirer?"Allah (SWT) and his Apostle know better", I replied. The blessed Prophet $(S A W)$ said: "certainly he is Jibreil; he had come to you to teach you your religion.",

\section{Views of Some Prominent Muslim Scholars on Tawhid}

The worldview of tawhid creates an environment in which man fears only one power; is guided by only one source; is answerable before only one judge; is turned to only one direction - Qibla; directs hopes, desires and expectations to only one Almightly and establishes direct link with the Creator, and consequently, destroys all forms of 'midgods' or their dehumanized portrayals. Again, all diverse and variegated tendencies of man are debased completely. Finally, the concomitant effect of the tawheedi environment is that it bestows upon man independence and dignity. It is because of the fact that submission to the almighty alone impels man to revolt against all lying, corrupt, dehumanized and exploitative powers. Throughout the Islamic history Muslim scholars, classical and modern, have elaborated on the concept of tawhid. A study of their discourses suggest that they have not only discussed the issue of tawhid from the theological point of view only but also from the civilizational aspect as well. For the sake of convenience some prominent Muslim scholars, as representatives, from both classical and modern era have been taken and their views

\footnotetext{
${ }^{11}$ Sahih al-Bukhari, Hadith No. 7372.

${ }^{12}$ Muhammad b. Abdullah al-Khatib, Mishkat-ul-Masabih (New Delhi: Islamic Book Service,
} 2009), Vol. 1, Hadith No. 95.

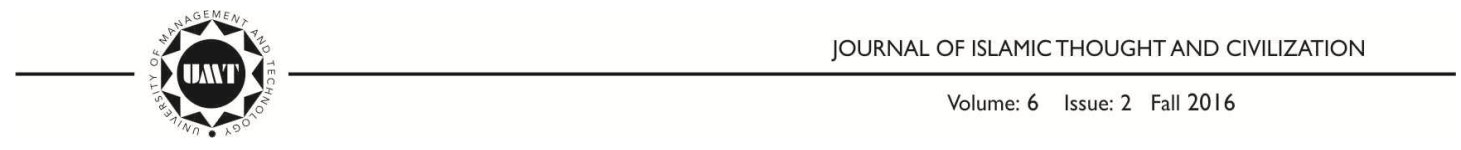


on tawhid have been analyzed which shows the richness in their thought and contents with respect to tawhid and the worldview that it proposes and impresses upon.

\subsection{Muhammad Ibn Jarīr al-Tabari}

Abu Ja'far Muhammad ibn Jarīr al- Tabari (d. 923 C.E.), Muslim scholar, author of enormous compendiums of early Islamic history and Qur'ānic exegesis, who made a distinct contribution to the consolidation of Sunni thought during the 9th century. He condensed the vast wealth of exegetical and historical erudition of the preceding generations of Muslim scholars and laid the foundations for both Qur'ānic and historical sciences. His major works were the Jami'al- Bayan (Qur'änic Commentary) and Ta'rīkh al-Rusul wa al-Mulūk (History of the Prophets and the Kings). Ibn Jarīr states that Islam rejects the notion of some cultural anthropologists that early religion of human beings was polytheism, then slowly the idea of monotheism evolved from that. He mentions a statement of Ibn 'Abbas $(R A)$ which says that "Between Noah and Adam were ten generations all of them were upon Shari'ah (law) of the truth, then they differed. So Allah sent prophets as bringers of good news and as warners." ${ }^{\prime 3}$ The Qur'ān says: "And We certainly sent into every nation a messenger, (saying), "worship Allah and avoid taghut (disobedience)."14

Ibn Jarir in his tafsir says that, "For each of you We prescribed a law (Shari'ah) and a method (Minhāj' (5: 48) i.e. a Sabeel (path) and a Sunnah (way). And the Sunan (ways) are different: for the Tawrah (Torah) there was a Shari'ah (laws), for the Injeel (Bible) there was a Shari 'ah, for the Qur'ān there is a Shari'ah, Allah permitted therein whatever $\mathrm{He}$ wished, and $\mathrm{He}$ forbade therein whatever $\mathrm{He}$ wished as a trial, so that it may be known who are those that obey Him from those who disobey Him. But the one Religion that is accepted is Tawhid and Ikhlās for Allah, that which the Messengers came with." ${ }^{\prime 15} \mathrm{He}$ also states that the meaning of what Allah said (is); "And We have not sent before you O Muhammad! (SAW) a messenger to one of the nations but that We revealed unto him that there is no worshipped being in the heavens or on earth besides Me who is worthy of worship, so worship Me, He said: So keep your worship purely for Me, and single only me with Uluhiyyah (worship). ${ }^{16}$

Qur'ān calls to the absolute oneness of Allah (SWT) (tawhid) in many ways. Ibn Jarir al-Tabari have analyzed this call comprehensively and found it to be broadly consisting of three dimensions:

\footnotetext{
${ }^{13}$ Muhammad Ibn-e-Jarīr al-Tabari, Jami' Al-Bayan An Ta'wil al-Qur'an (Riyadh: Dar Aalim al-Kutub, 2002),4/275.

${ }^{14} \mathrm{Al}$-Qur'ān, an-Nahl 16:36.

${ }^{15}$ Al-Tabari, , 10/385.

${ }^{16}$ Ibid, 18/427.

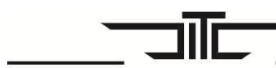

JOURNAL OF ISLAMIC THOUGHT AND CIVILIZATION 
1. Establishing the Oneness of Allah in His Lordship (al-tawhid alRububiyyah).

2. Devotion to all acts of worship to Allah alone (al-tawhid al-Uluhiyyah).

3. Establishing the Oneness of Allah in His Names and Attributes (al-Tawhid al-Asma wa al-Sifät).

While making the interpretation of the verse, 'Say, Allah is the creator of everything. ${ }^{17}$ Ibn Jarir points out that Allah is saying to His Prophet Muhammad $(S A W)$ : "Say to these polytheists when they affirm to you that their idols which they associate with Allah do not create a thing; Allah is your Creator, the Creator of your idols and the Creator of all things, so on what basis do you associate with Him something that cannot create or cause harm?" ${ }^{18}$ Allah mentions a conversation that took place when Musa called Pharaoh and his people to worship none but Him. ${ }^{19}$ On this Ibn Jarīr states that when He informed them of that which they knew to be the evident truth - since the kingdom of the Pharaoh and the kings before him did not reach beyond Egypt, and it had become clear to the Pharaoh and the people around him that He who Musa is calling them to worship is the King who owns all other kings - the Pharaoh was too proud to accept the truth and said in his utter misguidance to Musa. "If you take a deity besides me I will surely throw you in prison." ${ }^{20}$ It is evident that anybody who claims lordship and enslaves people based on this will be proven a liar by his own deficiency in lordship and the absolute Lordship of Allah. This will also be proven by the fact that $\mathrm{He}$ is the lord of each and everything that exists including the claimants of lordship, and from this, His sole right to be worshipped is concluded.

Regarding tawhid al-Uluhiyyah, Ibn Jarī says that Allah rebuked these polytheists who make deities of things He created and worship them along with Him, while affirming that these things (that they worship) are His creation and that they (the polytheists) are His slaves. ${ }^{21} \mathrm{He}$ is of the view that the whole universe is the Allah's creation and His slave and He only is worthy of worship, He is the Creator and Owner of everything including the deities they used to worship and this was a proof against them regarding worshipping Him alone. The Lord of the worlds who created all things and owns that which they worship besides Him is the one who truly deserves to be worshipped. After all, how can something created, owned, and is under His Lordship be worshipped with the Him, the One Who Created him and Owns him. While talking about tawhid al-Asma was-Siffāt, Ibn Jarī says that, "And indeed He, exalted by His remembrance, means by His saying, 'Neither sleep nor slumber

\footnotetext{
${ }^{17} \bar{a} \mathrm{l}-\mathrm{i}-\mathrm{Imrān}$ 13:16.

${ }^{18}$ Ibid, $13 / 496$.

${ }^{19}$ Al-Qur'ān, Shu'ara 26:23-29.

${ }^{20}$ Al-Tabari, op. cit., 17/564.

${ }^{21}$ Ibid., 20/ 96.
}

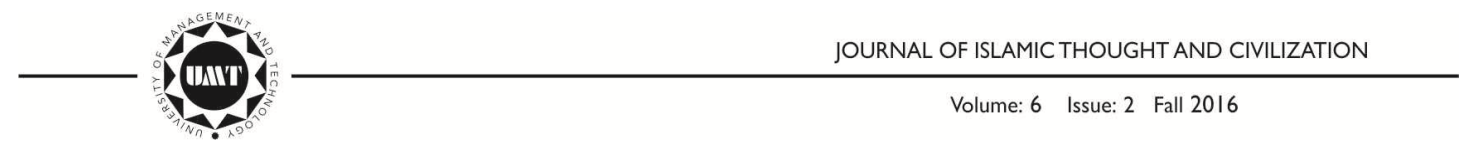




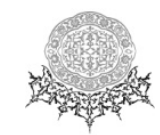

overtakes Him' that aafaat (deterioration and the likes) do not occur to Him and 'aahaat (maladies) do not affect Him, and in the one whom they afflict they put an end to the state, condition which he was upon before they afflicted him." So the explanation of the speech, "Allah $(S W T)$, there is none worthy of worship except He, the ever - Living (al-Hayy) who never dies, the self-Sustainer (al-Qayyum)' who sustains everything besides Him with sustenance, and preservation, and regulation and management from one state, condition to another state condition. Neither sleep nor slumber over takes Him, and that which changes others does not change Him, and the changing, transforming (tanaqqul) of states, and the passing of nights and days do not cease from Him what $\mathrm{He}$ has never ceased to be upon. Rather, $\mathrm{He}$ is the continuous upon state, condition, and the self-Sustaining who sustains all of the creation, if He slept He would be overcome, subdued, because sleep overcomes the sleeper and subdues him. ${ }^{22}$

Thus, it is evident from the above discussion that Ibn Jarīr have categorized the tawhid in various sections like Uluhiyyah, Rububiyyah and al-Asma wa-Siffät. Ibn Jarir believes that the meaning of the verse should be taken as on its basic meaning (zaahir), until the proof that changes its meaning from basic to another.

\subsection{Ibn-e-Kathīr}

Abul Fida Ismaa'eel ibn Kathīr al-Dimashqi, originally from Basra (Syria) and was raised in Damascus. He followed the Shafi ee school of thought. Ibn Kathir was born in the year $700 \mathrm{AH}$ or little later in an area called Majdal, near Basra, west of Damascus. His father died when he was only four years old and was taken in by his brother and moved to Damascus in 706. Here, he learned from great scholars such as Ibn Asakir, Ishaq ibn Yahya al-Amudi and the great Ibn Taymiyyah who was extremely close to him. He also studied under various other sheikhs who gave him permission in fiqh and Hadith. He made many academic contributions to Islamic sciences. While talking on the concept of tawhid, Ibn kathīr in his tafsir states that Allah $(S W T)$ says that the fact He is One and that He is independent in His creation, control, dominion and guides one to realize that there is no God except Him and that none should be worshipped except Him alone, with no partner or associate. He tells His messenger Muhammad ( $S A W$ ) to say to the idolaters who worship others besides Him, even though they admit His Lordship, that He has no partner in Lordship. But despite this they still attribute partners in divinity to Him, and worshipped others besides Him even though they recognized the fact that those whom they worshipped could not create anything. However, they still believed that these creatures could bring them closer to Allah. ${ }^{23}$ Allah affirms that there is no deity worthy of worship

\footnotetext{
${ }^{22}$ Ibid., 3/12.

${ }^{23}$ Ibn Kathir, Tafsir Ibn Kathīr, Vol. 6 (Riyadh: Darus Salam Publishers and Distributors, 2000), 680 .
}

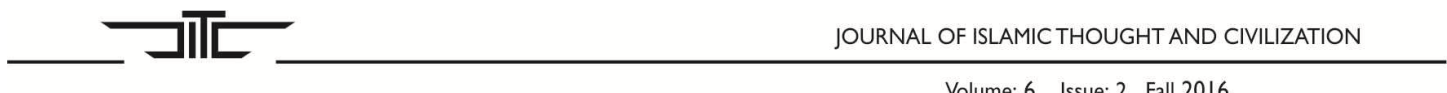


except Him, since they admit that He alone created the heaven and the earth and that $\mathrm{He}$ is their Lord and the Disposer of all affairs. Yet, they take as lords others besides Allah and worship them, even though these false gods didn't have the power to benefit or harm themselves, or those who worship them. Therefore the polytheists will not benefit or have harm removed from them by these false deities. Those who worship Him alone, without partners, will thus have a light from their Lord. ${ }^{24}$

The basic concept Glorious Qur'ān envisages is the adoration of one true God Allah. This has to be performed as the noblest creature and vicegerent of God - as a fully- integrated being committed to cosmic mission. He should have complete faith that Gods personality enshrines the perfect Ideal of Integration and man is his viceroy. His adoration should therefore be dynamic and comprehensive. It should be vast and expansive, not confined to worship only. It should encompass the development of whole personality, launching of societies for the welfare and amelioration of the individual and community, raising their socio-economic, cultural, educational, scientific and technological level to state where they could ponder, reflect and observe and unravel the vast impregnable mysteries and knowledge hidden in Nature. This would also give man a chance in the pursuit of physical sciences and make him active crusader for the spiritual and moral emancipation of humanity and the establishment of social, economic and political justice as ordained by the Qur'ān.

Allah states that the Christians are disbelievers, who say that Isa is Allah. Allah is far holier that what they attribute to Him. They made this claim in spite of the fact that Isa made it known that he was the servant of Allah and His messenger. The first words that Isa uttered when he was still a baby in the cradle were, "I am Abdullah (the servant of Allah)." He did not say, "I am Allah," or, "I am the son of Allah." ${ }^{, 25}$ Is there a god, besides Allah, they will say, "Allah." Allah argues that the idolater's recognition of Allah's oneness in lordship is evidence against them, for which they should admit and recognize the Oneness in divinity and worship. ${ }^{26}$ Allah shows His servants that they should worship Him alone, for just as He is independent in His power of creation and provision, so He should be worshipped alone with no partners or associates such as idols and false gods. So Allah's, "(La ilaha illa Huwa. How then are you turning away from Him). Meaning how can you turn away from Him after this has been made clear and this proof has been made obvious, but you still worship idols and false gods? And Allah (SWT) knows best.",27

Thus tawhid is essentially a doctrine of knowledge and Islam is the path of knowledge; an idea unambiguously presents and rooted in the Shahadah which primarily seeks to implant knowledge and certitude through its axiomatic statement.

${ }^{24}$ Ibid., 5/257.

${ }^{25}$ Ibid., 3/ 234.

${ }^{26}$ Ibid., 4/ 600 .

${ }^{27}$ Ibid., 8 /122.

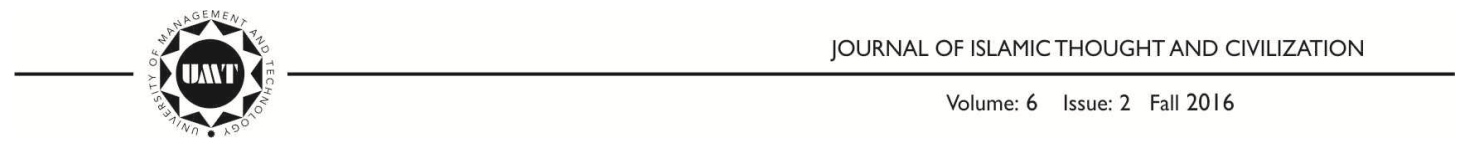




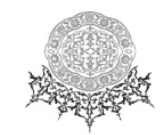

Islam, thus, starts by believing and knowing simultaneously, since the Shahadah constitutes a complete fusion of faith and knowledge, a doctrine very characteristic of Islam. Christianity is a doctrine of union rather than unity, hence it insists on love rather than unity; while Islam is a doctrine of unity, hence it insists on knowledge because only knowledge can realize the maximum of unity. But in principle knowledge is more than love.

\subsection{Mufti Muhammad Shafi}

Muhammad Shafi ibn Muhammad Yasin Usmani (d.1976), often referred to as Mufti Muhammad Shafi, was a South Asian, Hanafi, jurist and mufti, he was also an authority on Shari'ah, Hadith tafsìr (Qur'ānic exegesis), and tasawwuf (Sufism). Born in Deoband, British India he graduated in 1917 from Darul Uloom Deoband where he later taught hadith and held the post of Chief Mufti. He resigned from the school in 1943 to devote his time to the Pakistan Movement. After the independence he moved to Pakistan, where he established Darul Uloom Karachi in 1951. His best-known work is Ma'ariful Qur'ān, a tafsīr of the Qur'ān.

In the unitary perspective of Islam, all aspects of life as well as all degrees of cosmic manifestation, are governed by a single principle and are unified by a common centre. Tawhid is the eternal, changeless principle that serves as the basis for change and variety in Islam. Doctrine of Tawhid, the oneness of Allah, is the basic point of difference between Islam and other religions and between a disbeliever and a true Muslim. The doctrine of Tawhid was professed and brought by all the prophets in earlier times. From Adam to the last Prophet $(S A W)$ up to some one hundred and twenty four thousand Prophets were born in different periods speaking different languages, living in different countries. All of them told and taught the same truth. And when the Qur'ān came it didn't present any new claim which could pose problems for people in its understanding or acceptance, but it simply confirmed their truth. $^{28}$

Regarding the Oneness of Allah, Mufti Muhammad Shafi states that Allah is the personal name of that necessary Being whose non-existence is inconceivable. He comprises all the attributes of perfection and is free from, or above, or overrides all kinds of imperfection. the epithets ahad and wähid are both applied to Allah which are normally translated as "one" but the word ahad includes an additional sense which signifies that Allah is beyond composition, plurality an resemblance, which means that $\mathrm{He}$ is neither composed of any elements, nor does He have any partner nor has He any resemblance to anything. While interpreting the word As-Samad, he says that originally it refers to the chief who has no superior and to whom the people turn for the fulfillment of their desires and needs, thus all people depend on $\mathrm{Him}$, but $\mathrm{He}$

\footnotetext{
${ }^{28}$ Mufti Muhammad Shafi, Ma'ariful Qur'ān vol., 2 (New Delhi: Farid Book Depot (P) Ltd., 2000), 42.
}

$\frac{1 \|[}{\text { JOURNAL OF ISLAMIC THOUGHT AND CIVILIZATION }}$ 
doesn't depend on any one. In the commentary of Suratul Ikhlas he says the following four points:

1. He is one in the state of His Being that is there exists none in the universe of His creation and entity like Him. He is without any duplicate or replica and without any equal or parallel. Such unshared and pristine is His station that He alone is deserving of being called the wahid, the one.

2. He is One in claiming the right of being worshipped, that is, in view of the nature of His Being, the comprehensiveness of His most perfect attributes and the great charisma of His creation and its nurture, all human, obedience, all ibadah, all worship has to be for Him alone.

3. He is the One in being free of any conceivable composition, that is, $\mathrm{He}$ is free of segments and fragments, atoms and particles. There is just no way He can be analyzed or divided or resolved.

4. He is One in being the anterior and posterior, that is, He existed when nothing did and $\mathrm{He}$ will remain existing when nothing will. Who than if not Him, shall be Wahid, the only one ? $^{29}$

\subsection{Abul Ala Maududi}

Abul Ala Maududi (d. 1979) has written over 200 books and pamphlets and made over a 1000 speeches and press statements of which about 700 are available on record. Some of his writing has been translated into English, Arabic, Turkish, Persian, French, German, and other languages. Mawdudi's pen was simultaneously prolific, forceful and versatile. The range of subjects he covered is unusually wide. Disciplines such as Tafsir, Hadith, law, philosophy and history, all have received the due share of his attention. He discussed a wide variety of problems, political, economic, cultural, social, and theological and attempted to state how the teachings of Islam were related to those problems. Maududi has expounded the essentials of the Islamic approach in most of the fields of learning and inquiry. His main contribution, however, has been in the fields of the Qur'ānic exegesis (Tafsìr), ethics, social studies and the problems facing the movement of Islamic revival. His greatest work is his monumental tafsir in Urdu of the Qur'ān, Tafhim al-Qur'ān, a work he took 30 years to complete.

All prophetic missions were aimed at the bringing about revolutionary change for the benefit of the human kind. It was realization of the ideals of the wisdom, brotherly love, reduction of human misery and stimulation of the sense of the independence and responsibility. All these aspirations and ideals are summarized in the principle of tawhid. According to Maududi, among the fundamentals of Islam, the most important is belief in one God (tawhid), not just the conviction that He exists or that $\mathrm{He}$ is one - but that He alone is Creator, Master, Ruler and Administrator of all

${ }^{29}$ Ibid., Vol. 1, 414-415.

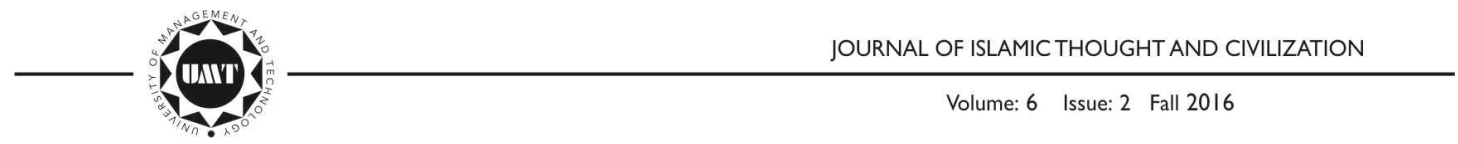




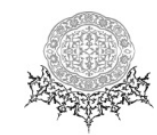

that exists. The universe exists because God wills it to exist, it functions because God wills it to function and God provides that sustenance and the energy which everything of the universe requires for its existence. He further says that anyone who doesn't look around like an animal but makes an intelligent observation of the great system of the universe that is working day and night before his very eyes, and is not blinded by the prejudice or obduracy, can see many signs pointing to the Reality. He will certainly see that it is being ruled only by the All-Powerful, All Wise-Sovereign. He can also understand that Allah alone is the God of the whole universe and that there is absolutely no room for any kind of interference or partnership, for no one has any quality or power or authority to entitle him to the claim of Godhead. ${ }^{30}$

While centering himself on an analysis of the two words used for God in the Qur'ān, Ilāh (Master and Sovereign) and Rabb (Lord), his conception of the unity of God is not a mere religious creed but the whole system of social life which is based on the conception that man is an independent being or that Sovereignty belongs to any other being animate or inanimate, is uprooted from foundation and a new superstructure rise on a different basis with belief in the oneness and sovereignty of God. It summons to give absolute obedience to God. He is worshipped with everything heart as well as body. ${ }^{31}$ Nothing can be left out of His Lordship, He is the Creator, Master and Real Patron of the universe and man. He alone is man's Ruler, He alone has the right to give man the faith $(D \bar{i} n)$ and Law (system of belief and practice) and judge the disputes of man and tell what truth is and what falsehood is. No other being has any right whatever to be man's lawgiver. In other words, the sovereignty with regard to law-making also is vested only in Allah. No man or creature apart from Allah can be the bearer of the Sovereignty. And if a person doesn't recognize and accept this divine rule of Allah, it is merely futile for him to recognize the natural sovereignty of Allah. ${ }^{32}$ Accordingly Mawdudi articulates that, Islam makes all life God-Centered. To accept the reality of the creator is to accept Him as the only Lord, the only source of guidance. Accepting that and being under His rule brings all life. That is to say, that edifice of a complete Islamic life can only be built on a belief in God's Unity (tawhid) that permeates a man's entire personal and social life and which is so strong that he considers himself and all that he possesses as belonging to God; he accepts Him as the sole rightful owner, object of worship, receiver of obedience and law-giver for himself as well as the rest of the world; he considers Him the fountainhead of guidance. Therefore, as God is one (tawhid) so all of His creation has an underlying unity and is subject to His rule.

${ }^{30}$ Abul Ala Maududi, Tafheem ul-Qur'ān (New Delhi: Markazi Maktabi Islami) Vol. 1, 130-

131.

${ }^{31}$ Abul Ala Maududi, Political Theory of Islam (New Delhi: Markazi Maktaba Islami, 1981),

20.

${ }^{32}$ Mawdudi, Tafheem, op. cit., Vol. 4, 475-476.

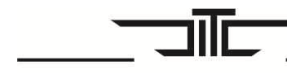

JOURNAL OF ISLAMIC THOUGHT AND CIVILIZATION

Volume: 6 Issue: 2 Fall 2016 
Maududi also identified the intimate relationship between tawhid and state. So nothing can be left out of His Lordship, not even the tiniest territory in life, in heart or in behaviour. Thus God as a Sovereign Ruler, and man, as His vicegerent, must implement His rule on earth. As he writes, "the state, according to Islam is nothing more than a combination of men working together as servants of God to carry out His will and purpose." ${ }^{, 33} \mathrm{He}$ stresses, "It is clear to us that the Din (Religion) propagated by the Qur'ān has three most basic beliefs. One is Tawhid, the second being Prophethood and third, the belief in the world Hereafter and since chapter Ikhlas (Sincerity), deals with Tawhid hence it is, termed as the one-third of the Qur'ān." "34

\subsection{Ismail Raji al-Faruqi}

Ismail Raji al-Faruqi (d. 1986) was a Palestinian Islamic scholar, writer, and activist and Governor of Galilee (1945 - 48). He was professor at universities in Africa, Europe, the Middle East, and South and Southeast Asia. His works focus on a comprehensive vision of Islam and its relationship to all aspects of life and culture. Al-Faruqi presented Islam as a religion of reason, science, and progress, emphasizing action and the work ethic. He combined the classical affirmation of God's Oneness (tawhid) with a modernist interpretation and application of Islam to modern life through the exercise of ijtihad. He established Islamic studies programs, recruited and trained Muslim students, organized Muslim professionals, and was an active participant in international ecumenical dialogue. He co-founded the International Institute for Islamic Thought in the United States in 1981. He regarded the political, economic, and religio-cultural malaise of the Islamic community as a product of the bifurcated state of education in the Muslim world, which has resulted in a loss of identity and world vision. He believed the cure was the compulsory study of Islamic civilization and the Islamization of modern knowledge.

Ismail Raji al-Faruqi discussed the practical implications of tawhid, focusing on Muslim responsibility for all of humanity and the entire cosmos since Muslims are the beneficiaries of perfect and complete revelation. Such responsibility demands an Islamic world order oriented toward human activity in public action, rather than excessive legalism, materialism, or spirituality alone. Tawhid commands that all life must be ordered according to divine will. He identifies the doctrine of tawhid as "the essence and core of Islam"; it is, in fact, the "first determining principle of Islam, its culture and civilization." This is so he asserts, because tawhid is that which gives Islamic civilization its identity which binds all its constituents together and makes of them an integral, organic body. ${ }^{35} \mathrm{He}$ also states that tawhid is a general view of

9.

${ }^{33}$ Abul Ala Mawdudi, Process of Islamic Revolution (Delhi: Markazi Maktabi Islami, 1959),

${ }^{34}$ Mawdudi, Talqees Tafhim-ul Qur'ān (Delhi: Markazi Maktaba Islami, 1996), 1044.

${ }^{35}$ Ismail Raji al-Faruqi, Tawhid: Its Implications for Thought and Life (International Institute of Islamic Thought, 1982), 18.

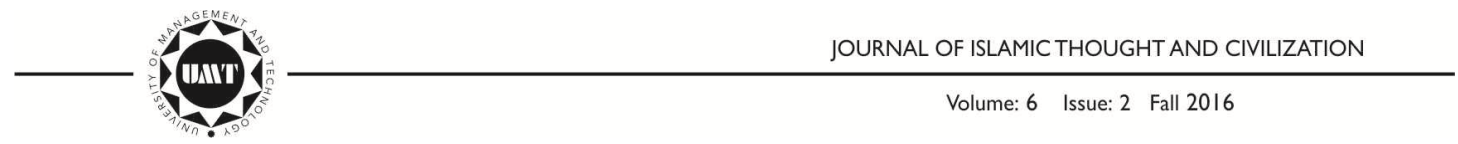


reality, of truth, of the world, of space and time, of human history and destiny. The original meaning of tawhid is the belief that God is one inalienable divinity. Thus He is the ultimate centre of Universae, the solo creator and administrator of the world. Tawhid is at the forefront of Islamic thought today due to a concern with the practical manifestation of Islamic Unity in a world fragmented by colonialism and nationalism. Tawhid has emerged as a powerful symbol of divine, spiritual and socio-political unity. Tawhid is that which gives Islamic civilization its identity, which binds all its constituents together and thus makes of them an integral, organic body that we call civilization. In binding disparate elements together, the essence of civilization in this case, tawhid impresses them with its own mold. It recompenses them so as to harmonize with and mutually support other rudiments. Without necessarily changing their natures, the essence transforms the elements making up a civilization, giving them their fresh character as constitutive of that civilization. The range of transformation may vary from slight to radical, depending on how relevant the essence is to the different elements and their functions. This relevance stood out prominently in the minds of Muslim observers of the phenomena of civilization. That is why they took tawhid as title to their most important works, and they pressed all subjects under its aegis. They regarded tawhid as the most fundamental principle that includes or determines all other principles; and they found in it the fountainhead, the primeval source determining all principals of Islamic civilization. ${ }^{36}$

\subsection{Amin Ahsan Islahi}

Amin Ahsan Islahi (d. 1997) was an India born, Pakistani Muslim scholar, famous for his Urdu exegeses of Qur'ān, Tadabbur-i-Qur'ān, and an exegesis that he based on Hamiduddin Farahi's (1863-1930) idea of thematic and structural coherence in the Qur'ān. Islahi was also a religio-political activist, thinker and wrote extensively on various issues faced by the Muslims in his time. He wrote several books covering a variety of subjects like Qur'ān, Hadith, jurisprudence, mysticism, philosophy, ethics, society and politics. But the most celebrated work of Islahi was his exegesis of the Holy Qur'ān. He offered different perspective on various religious issues.

Ameen Ahsan Islahi states that tawhid is the most significant issue in Islam. It is the centre of $\operatorname{Din}$ (Religion). It is the point where the faith originates. ${ }^{37}$ Islahi goes further and states that the rest of the two beliefs i.e., Prophethood and belief in the world hereafter are subordinate to the belief of tawhid. Hence the belief in oneness of God is the spirit of Islam. ${ }^{38}$ This belief occupies an important position in the teachings of all the Prophets. They preached and made efforts for the establishment of tawhid in

\footnotetext{
${ }^{36}$ Ibid., 90.

${ }^{37}$ Amin Ahsan Islahi, Haqeeqat-e-Tawhid (Delhi: Markazi Maktaba Islami, 1990), 10.

${ }^{38}$ Ibid., 110-111.
}

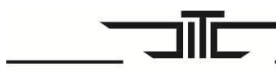

JOURNAL OF ISLAMIC THOUGHT AND CIVILIZATION 
its purest form. ${ }^{39}$ It is not only the part of Din but engulfs the whole $D \bar{i} n$ without which we can't even think of Islam.

Surah Ikhlas is called the surah (chapter) of tawhid because the doctrine of Allah (SWT)'s Unity and Oneness has been beautifully summed up in this surah. The message of the Qur'ān can be divided into three distinct topics: Tawhid (Monotheism), Risalat (Prophethood) and Ma'ad (The hereafter) which means that Tawhid occupies one third of the Qur'ānic context that is scattered in various surahs. Its core is epitomized in this comprehensive surah. Thus, in the summary of this surah Amin Ahsan Islahi commented that the message of surah lies in the concept of tawhid it brings out by mention of certain complementary pairs of attributes of God. The essence of which is that God has always existed and shall always exist; He was when there was nothing and shall remain when everything ceases to be; He is complete and entire in His being and is above all needs; everyone needs Him while $\mathrm{He}$ needs none; $\mathrm{He}$ is a refuge for all and on Him everyone depends; $\mathrm{He}$ brings everything into existence, and by His orders everything is destroyed; He is father to none nor has $\mathrm{He}$ a father; $\mathrm{He}$ is the Creator and the Cherisher of all and fashions and sustains everything; nothing is from His substance and being; He has no peer or equal and indeed all are his servants and slaves. ${ }^{40}$ In the explanation of the verse:

And your Allah $(S W T)$ is One Allah (SWT), There is no god but He, Most Gracious, Most Merciful. Behold! in the creation of the heavens and the earth; in the alternation of the night and the day; in the sailing of the ships through the ocean for the profit of mankind; in the rain which Allah (SWT) Sends down from the skies, and the life which $\mathrm{He}$ gives therewith to an earth that is dead; in the beasts of all kinds that $\mathrm{He}$ scatters through the earth; in the change of the winds, and the clouds which they Trail like their slaves between the sky and the earth; (Here) indeed are Signs for a people that are wise. ${ }^{41}$

Amin Ahsan Islahi states that if one reflects on this verse, it becomes evident that it cites parallel, in fact opposing, elements of nature which at the same time display amazing harmony and unity in the overall service, which they do for this universe. A perfunctory look at each member of the pairs the verse refers to shows that they are opposite of one another, the heavens and the earth, the night and the day, the ships and the seas. However, a deeper look shows that if from one aspect they seem opposite to one another, then from another they seem to complement one another for the overall benefit and well-being of this universe. Without the sky and its glowing suns and glittering stars, the earth would lose its liveliness and prosperity and in fact would cease to exist. Similarly, without this earth who can tell, many stars and heavenly bodies would gravely affected. Similarly, just as our life and that of other

\footnotetext{
${ }^{39}$ Ibid., 114.

${ }^{40}$ Amin Ahsan Islahi, Tadabbur-i-Qur'ān (Kuala Lumpur: Islamic Book Trust Malaysia, 2007),10.

${ }^{41}$ Al-Qur'ān, al-Baqara 02: 163-164.
}

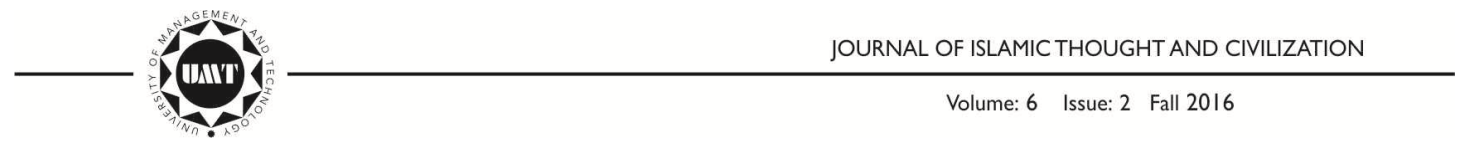




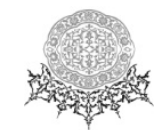

living things of this earth is dependent on the light, heat and freshness provided by the day, it is also dependent on the calm, peace and cool of the night. It is both night and day unison which guarantee life on this earth.

The next part of the verse mentions rain from the heaven which once again sustains life and vivacity and once again embellishes the surface of the earth with greenery and vegetation. Similar is the relation between clouds and winds, heaps and mounds of moisture laden clouds stand their ground unless strong winds push them and propel them to various. ${ }^{42}$

\section{Conclusion}

Tawhid is the key concept of Islam. It sums up the Islamic way of life and presents, in a nut shell, the essence of the Islamic civilization. It is also the one term which describes the process of the Islamic transformation of an individual or a society. In human history it presents the crux of the prophetic mission, having been the sheet anchor of all revealed religions. It is specially suited to describe the characteristic and abiding contribution of the last of the prophets, Muhammad $(S A W)$ in history. Tawhid, in fact, is the essence of being human for, the inculcation of this attitude in man means the restoration of human dignity which has been the central task before all revealed religions. The role of Divine guidance in man's life is to remind him of the ways that suit his own nature and the world of nature around him, and tawhid has always been the essence of such guidance. Tawhid remains at the epicentre of Islamic worldview. It is that which gives Islamic society its identity, which binds all its constituents together and thus makes of them an integral, organic body which we call civilization. In binding disparate elements together, the essence of civilization, tawhid impresses them with its own mould. It recasts them so as to harmonize with and mutually support other elements. Without necessarily changing their natures, the essence transforms the elements making up a civilization, giving them their new character as constitutive of that civilization.

\footnotetext{
${ }^{42}$ Mizan tr.by Shahzad Saleem.
}

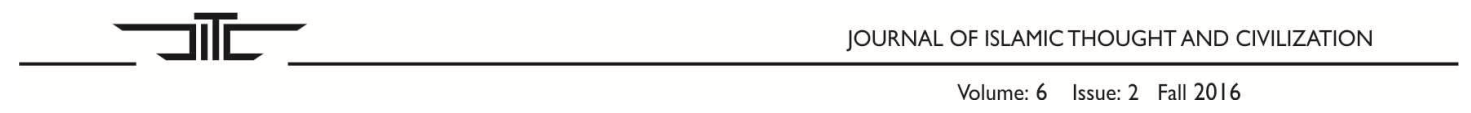

